\title{
Cerrados in Argentina? Structure, diversity and biogeography of the woody component of a savanna in the Misiones Province
}

\author{
Santiago José Elías Velazco ${ }^{1,3}$, Franklin Galvão ${ }^{1}$, Héctor Alejandro Keller $^{2}$ \& Natalia Alejandra Bedrij ${ }^{1}$
}

\begin{abstract}
The Teyú Cuaré field, in Misiones province, Argentina, has been renowned for its flora and physiognomy, which led researchers to indicate that it could be a relict of Cerrado biome. We analyzed the floristic structure of the woody component of a savanna community in this site, and discussed the processes that could contribute to the permanence of this vegetation type over time. Perimeter and height of all woody individuals $\geq 10 \mathrm{~cm}$ of perimeter at soil height were collected in 12 square plots $\left(400 \mathrm{~m}^{2}\right.$ each one). We found 15 families and 17 species in our site and compared the woody flora surveyed at this site with the flora of other Cerrado areas from Brazil and Paraguay. Leptolobium elegans had the highest importance value. The woody flora of the area is closely related to the Cerrado areas from Paraná state in Brazil and Canindeyú and Amambay in Paraguay. This site probably reflects old open physiognomies which were predominant in Misiones and Southern of Brazil in the late Pleistocene and middle Holocene. We inferred that the permanence of open physiognomies at Teyú Cuaré is probably related to mechanisms that act at different levels, such as geological, edaphic, anthropic, and fire disturbance.
\end{abstract}

Key words: Leptolobium, Cerrado, fire, phytosociology, relicts.

\begin{abstract}
Resumo
O campo de Teyú Cuaré no departamento de San Ignacio, na província de Misiones, Argentina, tem se destacado pela sua flora e fisionomia, o que levou a pesquisadores a indicar que poderia ser um relicto do bioma Cerrado. Analisou-se a florística e a fitossociologia do componente arbóreo-arbustivo de uma comunidade savânica, discutindo-se os processos que a originaram e contribuem para a permanência desta fitofísionomia. Em 12 parcelas quadradas de $400 \mathrm{~m}^{2}$ foram mensurados o perímetro e a altura de todos os indivíduos lenhosos com perímetro $\geq 10 \mathrm{~cm}$ ao nível do solo. Avaliamos a similaridade florística entre a área estudada e outras áreas de Cerrado do Brasil e do Paraguai. No total foram detectadas 15 famílias e 17 espécies, onde Leptolobium elegans foi a de maior importância estrutural. A flora lenhosa da área é mais fortemente associada com as áreas de Cerrado do Paraná e Canindeyú e Amambay no Paraguai. A vegetação do local possivelmente é um reflexo da expansão das fisionomias abertas do Pleistoceno tardio e Holoceno médio, dominantes em parte da província e do Sul do Brasil. A permanência desta unidade campestre provavelmente está relacionada à atuação de mecanismos de natureza geológica, pedológica, antrópica e por perturbações pelo fogo.
\end{abstract}

Palavras-chave: Leptolobium, Cerrado, fogo, fitossociologia, relictos.

\section{Introduction}

Savana vegetation is mainly characterized by the presence of a grass layer with woody elements, such as tall shrubs, trees or palm trees, in open formation (Sarmiento 1984). Neotropical savannas in the Caribbean and Central America are distributed in Cuba, Belize, Guatemala, Mexico, and Nicaragua. In South America, they are found in Colombia, Venezuela, Guiana, Brazil, Bolivia and Perú (Pennington et al. 2006). The largest Neotropical savannas are the Cerrado, distributed in Brazil, Bolivia and Paraguay; and the Llanos,

Supplementary material available at $<$ http://dx.doi.org/10.6084/m9.figshare.5238961>

${ }^{1}$ Universidade Federal do Paraná, Depto. Ciências Florestais, Av. Pref. Lothário Meissner 632, 80210-170, Curitiba, PR, Brazil.

${ }^{2}$ Universidad Nacional de Misiones, Facultad de Ciencias Forestales, Bertoni 124, C.P. 3380, Eldorado, Misiones, Argentina.

${ }^{3}$ Author for correspondence: sjevelazco@gmail.com 
in Venezuela and Colombia. The Cerrado is considered one of the most diverse savannas in the world with more than 12,000 vascular plants (Mendonça et al. 2008). Despite being the second major biome in Brazil, its geographical domain suffered changes of expansion and retraction throughout the Quaternary period (Durigan 2006).

The presence of vegetation types that are different from the main landscape is an evidence of the spatial dispute perpetrated by different biomes (Ledru 2002; Mayle 2006; Cox \& Moore 2011). Savannas in South America experienced cycles of expansion and retraction because of climate fluctuation (Werneck et al. 2011; Rull et al. 2013). When climate got drier, it favored the expansion of open physiognomies, such as savannas and grassland, and when climate got wetter, savannas suffered contraction, because climate was suitable for the closed formation (Sanaiotti et al. 2002; Ab'Sáber 2003; Alizadeh et al. 2015). Regarding Cerrado, relict and disjunction of this biome can be found as far from its current distribution area as in the Brazilian states of Roraima, Amapá, Piauí, Maranhão, São Paulo and Paraná (Ab'Sáber 2003; Ratter et al. 2003; Moro et al. 2015), as well as in other countries, in Bolivia and Paraguay (Villarroel et al. 2009; Mereles 2013).

In the Misiones province (Argentina), the flora comprises mainly forests, savannas, and grasslands. With one-third of the total number of vascular plants registered in Argentina (c. 3,400 species), it is one of the most biodiverse areas of the country (Zuloaga et al. 1999; Flora del Conosur $<$ http://www.darwin.edu.ar/Proyectos/ FloraArgentina/fa.htm $>$ ). Within Misiones, San Ignacio department has been highlighted for its floristic attributes due to the presence of taxa that, even though they have major distributions in other places, are restricted around the country, as well as high endemism levels (Cabrera 1987; Filgueiras 1990; Biganzoli \& Romero 2004; Fontana 2005; Krapovickas 2012a; Krapovickas 2012b; Keller 2015; Keller \& Tressens 2016). Less than $3 \mathrm{~km}$ to the southwest of the city of San Ignacio exist a singular vegetation locally known as Teyú Cuaré field. Due to its scenic and ecological relevance (Fontana 2005), it is considered an important Argentinian grassland and savanna site, closely related to Uruguay and Southern Brazil vegetation (Bilenca \& Miñarro 2004).

The Teyú Cuaré field is an open vegetation patch located inside a forest matrix. It covers around 200 ha and is in the buffer zone of two protected area, the Osununú Private Reserve and Teyú Cuaré Provincial Park. There are more than 179 plant species in Teyú Cuaré (Biganzoli \& Romero 2004; Fontana 2005), of which Leptolobium elegans Vogel (=Acosmium subelegans (Mohlenbr.) Yakovlev) (Fabaceae) and Allagoptera campestris Kuntze (Arecaceae) are remarkable, because of their restricted distribution into Argentina. In Teyú Cuaré field coexist grassland and savanna physiognomies. The population of Leptolobium elegans has a dense distribution to the north of the Teyú Cuaré field, and in the same way as other species, it emerges from the herbaceous layer as tortuous small tree, being responsible for the transitional grassland to savanna appearance of the landscape. This physiognomy associated with floristic composition led researchers to indicate that it is a relict of Cerrado biome (Martínez-Crovetto 1963; Chébez 1996; Biganzoli \& Romero 2004). The persistence of relictual vegetation can be associated with several factors, such as local climate (Moro 2012); geomorphology variation (PérezGarcía \& Meave 2004; Moro 2012; Spezialea \& Ezcurra 2012), edaphic conditions (Miranda et al. 2002; Carneiro Filho 1993), fire frequency (Behling \& Pillar 2007) or human activities (Iriarte $\&$ Behling 2007). Those environmental factors could be acting in the apparently relictual Teyú Cuaré field. Thus, we aimed to study the flora and structure of the woody component of the savanna portion of this area and to discuss some processes that gave rise to this vegetation type and contribute to its permanence in the region.

\section{Material and Method}

\section{Study area}

The study site is located in San Ignacio Department, Misiones, Argentina (Fig. 1) at 75-185 m a.s.1. (longitude: $55^{\circ} 33^{\prime} 26.62^{\prime \prime} \mathrm{W}$; latitude: $27^{\circ} 16^{\prime} 42.17^{\prime \prime} \mathrm{S}$ ). The majority of the Teyú Cuaré field is covered by grassland, so the plots for our phytosociological survey was placed on the northern part of this site, which presents a larger abundance of woody elements and savanoid physiognomy. The climate is Köppen, $C f a$, humid temperate with warm summers and cold winters, no distinguished dry season (INTA 1990). Mean annual temperature is $21.86^{\circ} \mathrm{C}$ and mean annual rainfall is $1,644 \mathrm{~mm}$; rainiest period comprises October to February. The mean annual number of frost days is nine, occurring from May to August (Martínez-Crovetto 1963). 

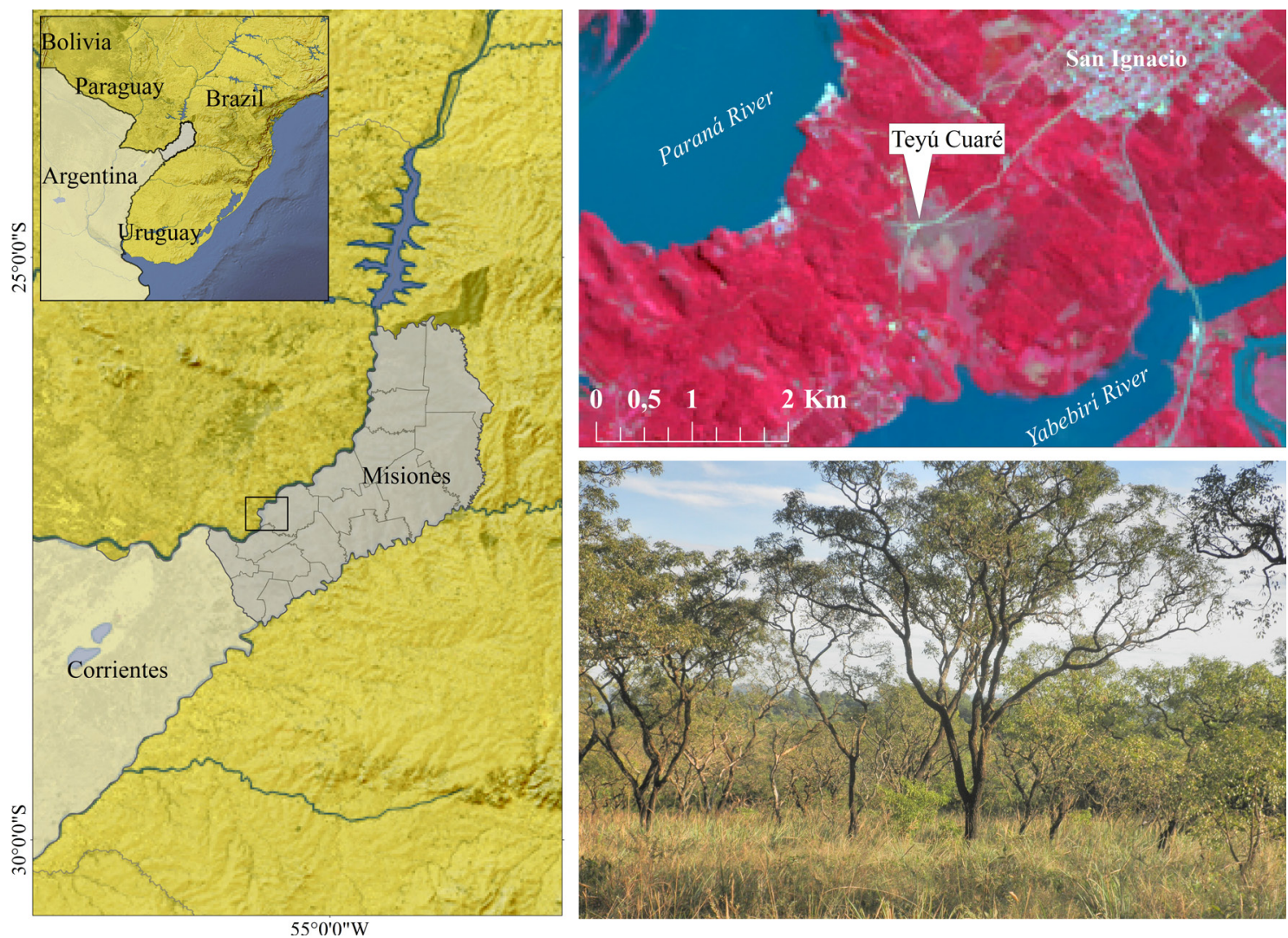

Figure 1 - Location of the research area in San Ignacio, Misiones - Argentina, and study site overview (bottom right).

The sandstone of Solari formation is predominant, which is notable considering that the province is mainly covered by basalt of the Serra Geral formation (Tchilinguirián et al. 2005). This sandstone relates to the Brazilian Botucatu formation (Teruggi 1970), as it is located above the Independência Series and under the eruptive Serra Geral (Harrington 1950). Posadas formation is also found in the site, with tholeiitic basaltic rocks (Teruggi 1970; Garrasino 1995). The study area shows a slightly undulate relief, with patches of sandstone outcrops.

Psamment and Entisol (IUSS 2015) are the predominant soils. The sampled soil profile (see supplementary material 1: <http://dx.doi. org $/ 10.6084 / \mathrm{m} 9$.figshare $.5238961>$ ) has $>65 \%$ of sand fraction, is acid, with low base saturation and cationic exchange capacity. Due to the sandy composition, with single-grain structure and very friable granules, the soil is highly susceptible to erosion.

Deciduous and semi-deciduous dry forests are the most common vegetation type in the region, and grasslands and savannas in the Southwest of the province gradually replace them. Based on the Martínez-Crovetto (1963) vegetation classification system, the study area comprises Distrito de los laureles, characterized by the presence of Lauraceae as Nectandra megapotamica Mez and Nectandra lanceolata Nees \& Mart, and the Distrito del Urunday, with Astronium balansae Engl. as the main species. Up to date, there are eight endemic species recognized for the Teyú Cuaré site: Austrochthamalia teyucuarensis (Apocynaceae) (Keller 2015), Gaya kelleri Krapov. (Malvaceae) (Krapovickas 2012a), Hedeoma teyucuarensis (Lamiaceae) (Keller \& Tressens 2016), Hyptis australis Epling (Lamiacease) (Epling 1949), Lessingianthus teyucuarensis (Cabrera) Dematt. (Asteraceae) (Cabrera 1987), Mesosetum comatum Swallen (Poaceae) (Filgueiras 1990), Oxypetalum teyucuarense Farinaccio \& Keller (Apocynaceae) (Farinaccio \& Keller 2014), and Sida rhizomatosa Krapov. (Malvaceae) (Krapovickas 2012b).

\section{Survey and data analysis}

We established 12 square plots of $20 \times 20 \mathrm{~m}$ $\left(400 \mathrm{~m}^{2}\right)$ randomly in the northern part of the open 
vegetation patch and measured all individuals with perimeter at soil height $\geq 10 \mathrm{~cm}$. Sampling sufficiency was assured by two criteria. The first was based on the individual-based rarefaction curve and its relationship with nonparametric species estimator Chao 1 and ACE (Abundance Coverage-based Estimator). A satisfactory survey is achieved when the sampled richness is equivalent or close to these estimators (Colwell 2013). Cain criterion (Mueller-Dombois \& Ellenberg 1974) was applied too, in which a satisfactory survey is reached when an increase of $10 \%$ in the sampling effort does not imply in a richness increment greater than $10 \%$. For this, we used the extrapolation curve (Colwell et al. 2012). We used EstimateS software v. 9.1.0 (Colwell 2013) to calculate Chao 1 and ACE estimators and perform the rarefaction and extrapolation curve with 100 individual randomizations.

Species names and their authors were updated according to the database of International Plant Name Index (<http://www.ipni.org/index. html $>$ ). Dispersion type and the habit were listed too. Community structure parameters (density, dominance, frequency and importance value) and Shannon diversity index using natural logarithms, Simpson's reciprocal and BergerParker's reciprocal were calculated (MuellerDombois \& Ellenberg 1974).

\section{Comparison with other study sites}

We performed ordination and cluster analysis in order to evaluate patterns of floristic similarity among the flora surveyed in Teyú Cuare and other savannah sites in the core and marginal Cerrado areas. Thus, we combined previous scientific publications of phytosociology and floristic lists with surveys of the Cerrado Domain in Brazil closer to the study site (states of Paraná, São Paulo, and Mato Grosso do Sul) and eastern Paraguay (departments of Amambay and Canindeyú) (Locations of the floristic surveys are depicted in the Figure 5, for more description for each site see supplementary material $2:<\mathrm{http}: / / \mathrm{dx}$.doi. org/10.6084/m9.figshare.5238961>). Our database encompassed 513 species and 66 areas, which 53 were sourced by the Conservation and Management of the Biodiversity of the Cerrado Biome Project (<http://cerrado.rbge.org.uk/cerrado/index.php $>$ ), published by Ratter et al. (2003). For the floristic studies, we just considered trees and large shrubs. The accepted names of taxa were verified using Taxonomic Name Resolution Service Version 1.1.
(Boyle et al. 2013) prior to analysis. Ordination and cluster analysis included those species that occurred in two or more sites (i.e., unicates were not considered); consequently, the final presences/absences matrix comprised 354 species (see supplementary material 3: <http://dx.doi. org/10.6084/m9.figshare.5238961>).

For ordination, we performed a Principal Coordinate Analysis (PCoA) based on Sørensen distance index. For cluster analysis, we applied Ward's hierarchical method with the same distance index used in the ordination. The best number of groups was assessed varying the number of cluster from 2 to 5 and performing the silhouette coefficient, in which the best is one that has the greatest coefficient value. The ordination and cluster analysis were performed in $\mathrm{R}$ v. 3.3.2 ( $\mathrm{R}$ Core Team 2016) with the vegan package.

\section{Results}

In the phytosociological study we measured 493 individuals, distributed in 17 species, 17 genera and 15 families (Tab. 1). Individual-based rarefaction and extrapolation curves, and ACE and Chao estimators, proved the sampling was satisfactory (Fig. 2). The asymptotic trend of the curve is proved by the proximity of the value of rarefaction curve and Chao 1 estimator, and to a lesser degree by the ACE estimator. For both estimators, the end of the rarefaction curve is within the confidence interval. The extrapolation curve predicts a weak richness increment with 500 additional individuals, again attesting a satisfactory sample (Fig. 2). Diversity values were 1.13 nats, 1.73 and 1.32 for the Shannon, Simpson's reciprocal and Berger-Parker's reciprocal index respectively.

Leptolobium elegans had the highest density (66.53\% of individuals), followed by Tabernaemontana catharinensis (14.20\%). All other species had values up to $3.85 \%$. Leptolobium elegans was the most dominant $(89.55 \%)$ and frequent species (24.49\%) too. Following it, Tabernaemontana catharinensis and Helietta apiculata were the species that shown the highest frequencies. Thus, L. elegans encompasses more than half the relative importance, followed by $T$. catharinensis and $H$. apiculata (Tab. 1).

The mean diameter of the woody plant community was $8.72 \mathrm{~cm}$, and the J-shaped distribution pattern of diameters was similar to sampled L. elegans individuals alone. This species showed the largest diameters $(28-31 \mathrm{~cm})$ (Fig. 3a). 


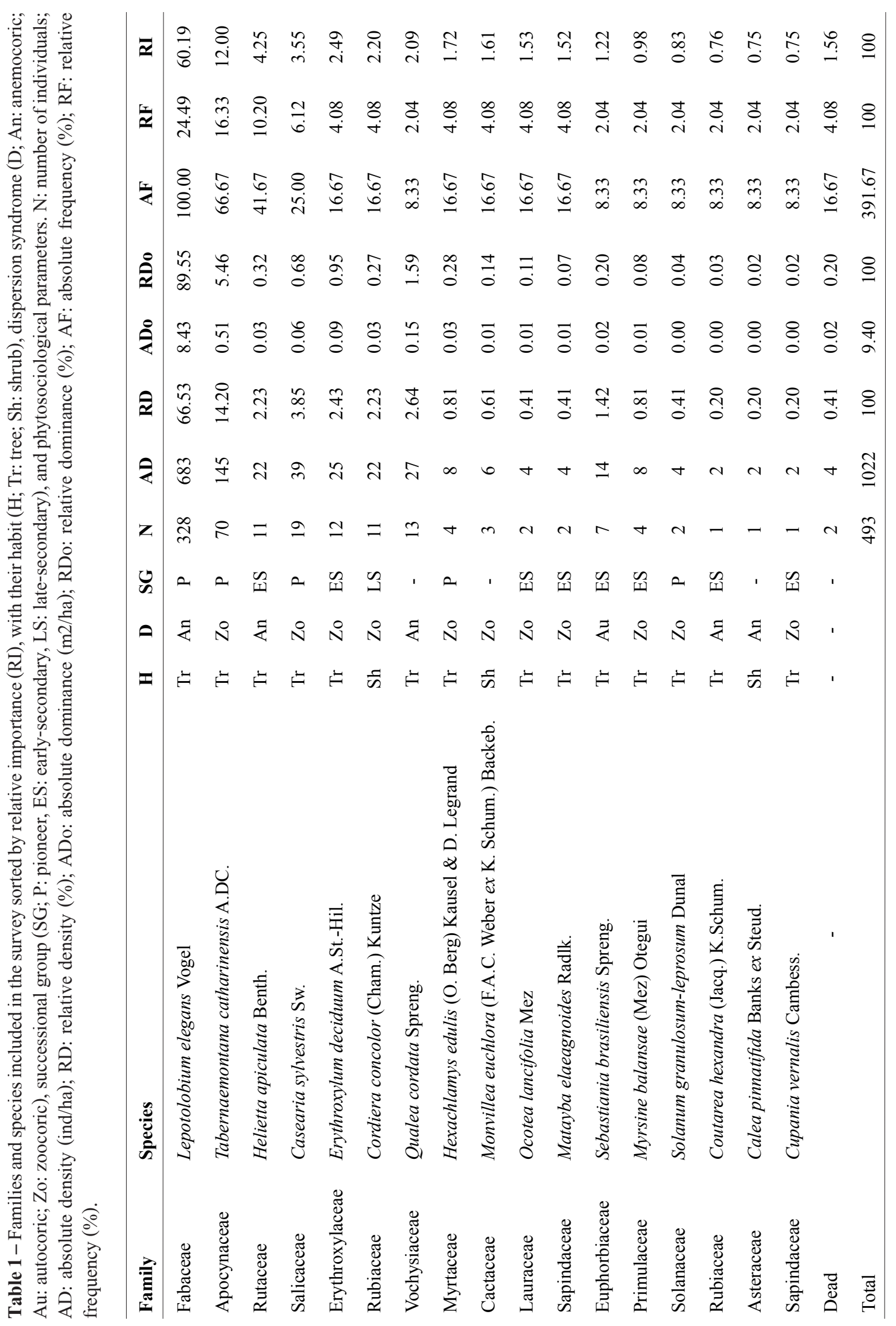




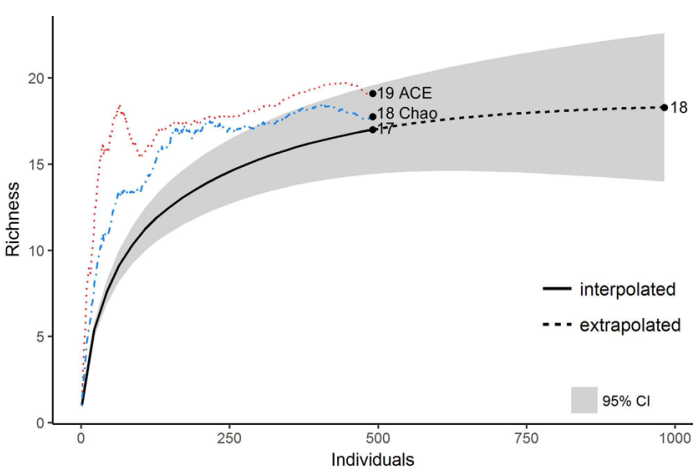

Figure 2 - Rarefaction and extrapolation curves, confidence interval at 95\%, ACE and Chao estimator, based on individuals surveyed in San Ignacio, Misiones, Argentina.

The mean height of the community was $3.30 \mathrm{~m}$. For the whole community and for other species the highest value was for the third class of height, while for L. elegans was the second class (Fig. 3b). Leptolobium elegans had the largest basal diameter mean and diametric range, followed by Qualea cordata and Erythroxylum deciduum. Cordiera concolor and Helieta apiculata presented the lowest values. This pattern was different regarding height, as Helieta apiculata and L. elegans showed the highest mean values, followed by Hexachlamys edulis and Erythroxylum deciduum. The lowest mean height was found in Qualea cordata and Cordiera concolor. Leptolobium elegans, $T$. catharinensis and Q. cordata were the species with largest height range (Fig. 4).

The ordination and cluster analysis revealed that the study site is strongly associated with the disjunct Cerrado patches from Paraná state in Brazil and those from Canindeyú and Amambay in Paraguay. It is possible to infer that the first ordination axis represents a latitudinal gradient (Figs. 5; 6a). Four groups were defined in the cluster analysis, which had a mean silhouette coefficient of 0.18: Group I - represented mostly by sites from the north and central Mato Grosso do Sul state; Group II - sites located near to the group in the south of Mato Grosso do Sul; Group III - the most spread group in geographical terms, all areas located at Southern study region, comprising sites from Argentina, Paraná state, and Paraguay; Group IV - sites from São Paulo state, to the East of the study site (Figs. 5; 6b).

\section{Discussion}

Structure, diversity and similarity

Stabilization of the rarefaction curve, as well as the values of the richness estimators, suggest that the sampling effort was enough to ensure correct description of species richness of the woody component. We sampled a richness constituted by 17 species, Leptolobium elegans was the main taxon that contributes the most to the structure of this savanna, with more than half of the relative
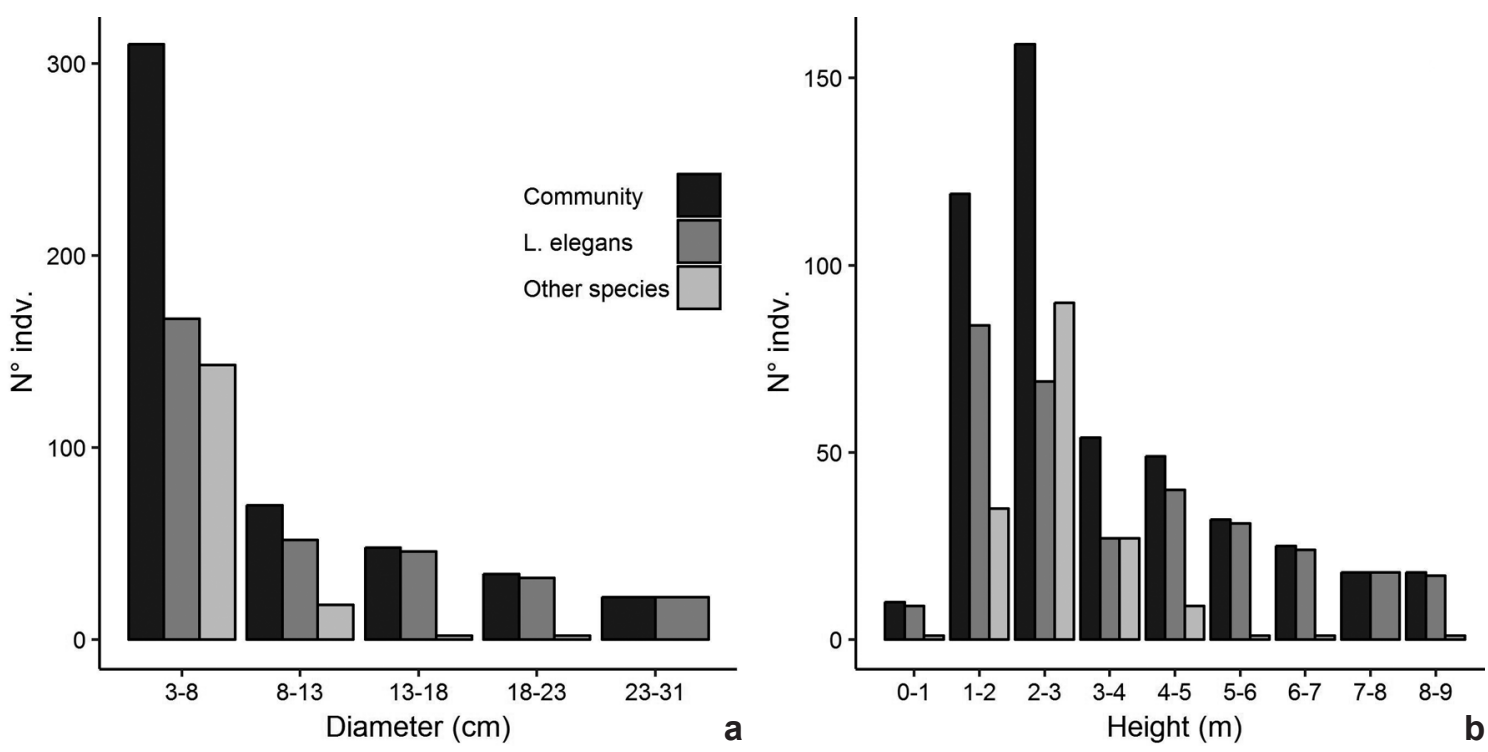

Figure 3 - Absolute frequency distribution of diameter (a) and height (b) classes for the community species (17 species), Leptolobium elegans individuals only, and other species than Leptolobium elegans (16 species). 

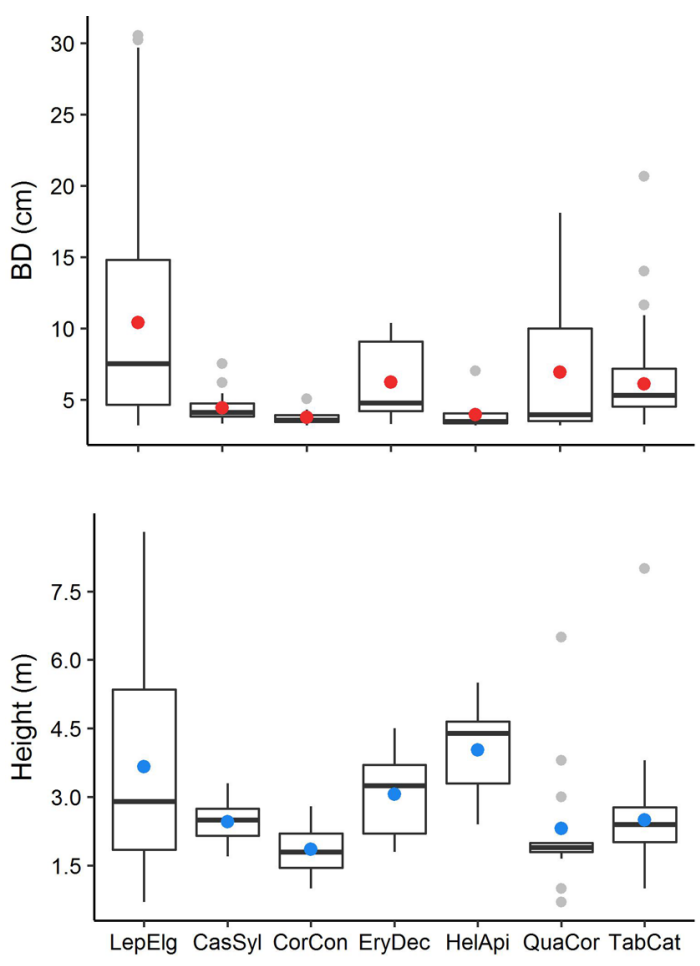

Figure 4 - Mean (points), median and quartile of the basal diameter (BD) and height of the most abundant species. LepEle: Leptolobium elegans, CasSyl: Casearia sylvestris, CorCon: Cordiera concolor; EryDec: Erythroxylum deciduum, HelApi: Helietta apiculata, QuaCor: Qualea cordata, TabCat: Tabernaemontana catharinensis.

importance, with the largest mean diameter and mean height. The low values of diversity and evenness are the result of the high dominance of L. elegans and the low number of woody species. L. elegans is a heliophytic species that inhabits different physiognomies mainly distributed in central-western Cerrado region (Ratter et al. 2003). It can withstand drought periods, as well as poor and well-drained soil (Burkart 1952; Lorenzi 2000; Rodrigues \& Tozzi 2012). Leptolobium elegans and Casearia sylvestris are two of the $11 \mathrm{key}-$ species in shrub-grassland and rupicolous Cerrado in Paraná and São Paulo states in Brazil (Moro 2012). Although Leptolobium elegans stood out in all phytosociological parameters, we also detected forest pioneer species, such as Tabernaemontana catharinensis, Casearia sylvestris, and Solanum granulosum-leprosum, and early secondary such as Helietta apiculata, Cupania vernalis and Matayba elaeagnoides.
Regarding Leptolobium elegans importance value, other studies achieved similar results. The species was one of the six more important in open grassland and typical Cerrado physiognomies in Paraná (Uhlmann et al. 1998) and São Paulo (Meira Neto 1991; Durigan et al. 2002; Toppa 2004; Ishara 2010; Ishara \& Maimoni-Rodella 2010; Prado Júnior et al. 2012). A typical Cerrado represents a savanna with sparse short arboreal elements of gnarled trunk and branches. Open grassland (campo limpo, in Portuguese) has a denser herbaceous vegetation with almost any arboreal component when compared to the typical Cerrado (Cerrado sensu stricto, Ribeiro \& Walter 2014). Regarding absolute dominance values (the area covered by the transection of all trunks present in the site), the data was similar to the dominance found in some areas of typical Cerrado (Uhlmann et al. 1998; Durigan et al. 2002; Ishara 2010), although we found lower values than other sites (Toppa 2004; Ishara \& Maimoni-Rodella 2010). Absolute density was similar to closed field (campo cerrado, in Portuguese) in Paraná (Uhlmann et al. 1998) and typical Cerrado in São Paulo (Durigan et al. 2002), and lower than other sites in São Paulo (Ishara 2010; Ishara \& Maimoni-Rodella 2010; Carmo et al. 2012). Most of the sampled individuals were included in the same height class identified in several other studies (Uhlmann et al. 1998; Toppa 2004; Ishara 2010; Ishara \& Maimoni-Rodella 2010). However, the studied community shows a different structure and diversity when compared with nearby forest environments (Velazco et al. 2015).

Despite the low diversity of woody species in the Teyú Cuaré field, it was floristically more related to some to the disjunct patches of Cerrado savannas in the extreme southern Cerrado region, such as those sites from Paraguay and Paraná state in Brazil. Many studies in savanna relicts in Brazil far from the core area of the Cerrado also showed poor woody richness, as in the prelitoranean plains from Ceará (Moro et al. 2011), a savanna in Rio Grande do Norte (Oliveira et al. 2012), the small patches in Paraná (Ritter et al. 2008; Moro 2012), or those found in Amapá, Pará, and Amazonas (Ratter et al. 2003). The southern region of the Brazilian cerrados are in a subtropical climate, facing frosts during the winter, and shorter dry season than in the core Cerrado biome (Durigan 2006), a quite similar condition to the Teyú Cuaré region. 


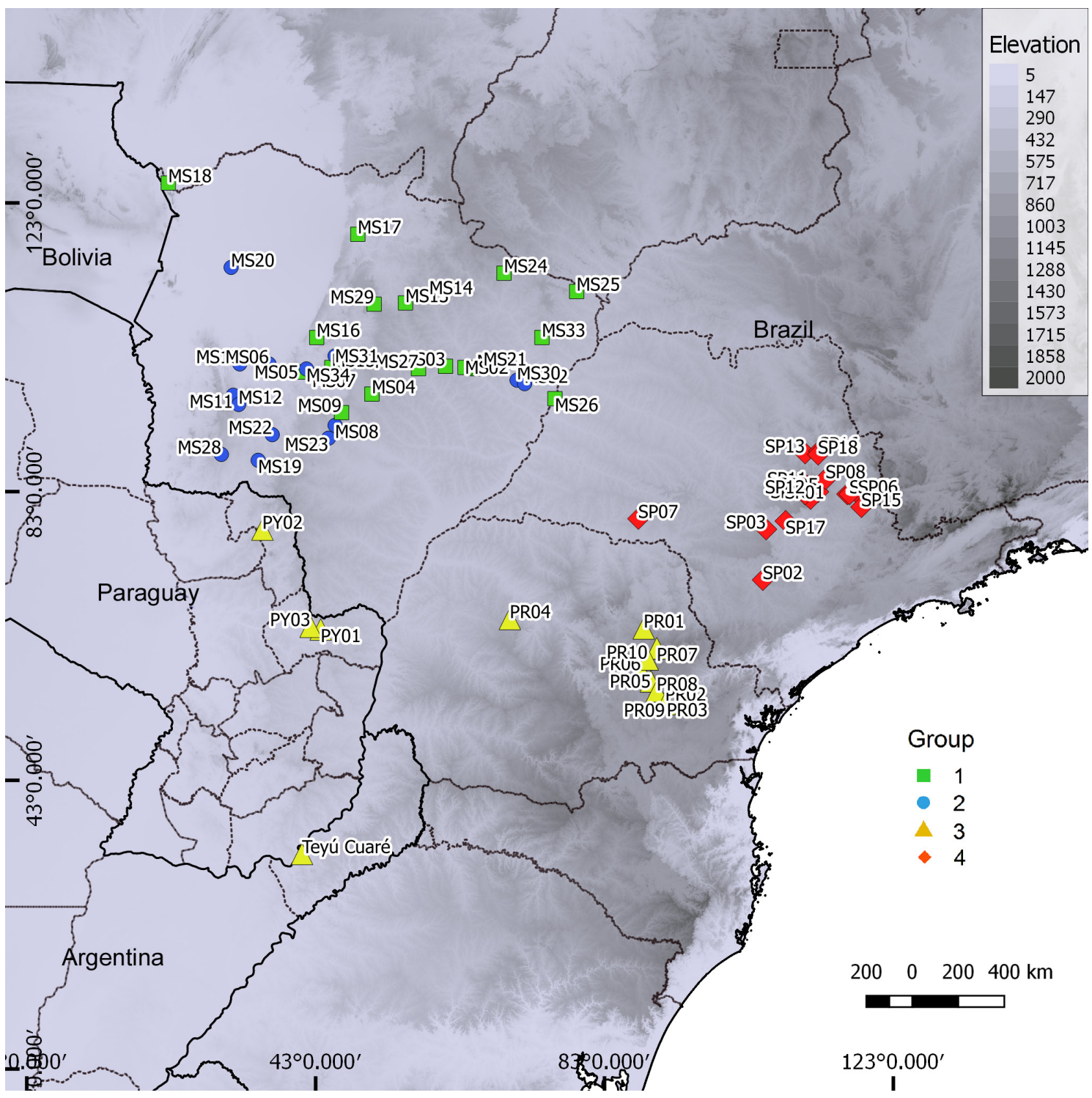

Figure 5 - Location of 66 floristic surveys of Cerrado's areas from Brazil, Paraguay, and Argentina -Teyú Cuaré-. Each color and shape represent different groups derived from the Ward's hierarchical method.

Factors related to the origin and permanence of open physiognomies

We hypothesize that the coexistence of an open vegetation formed by savanna and meadow and the surrounding forest is the result of historical and current factors affecting each physiognomy differently, such as: (1) Glacial-Interglacial Cycles: global climate cycles promoted the advance and retraction of open physiognomies, leaving relictual formations, which we consider responsible for originating the studied savanna patch. (2) The presence of ancient cultures: in Misiones province, archeological evidence exists of the ancient population, some of them are related to open physiognomies and used fire as a tool to clear vegetation. (3) Edaphic conditions: the soil profile analyzed in the forest presented more concentration of some nutrient than in the savanna, where poor nutrient soils prevail with higher aluminum saturation (Velazco 2014, see supplementary material 1: <http:// dx.doi.org/10.6084/m9.figshare.5238961>). (4) Disturbance events promoted by fire: in the studied area, burning is much more frequent in the savannameadows patch than in the forest surrounding it. Based on the Temaikèn foundation registries, in 

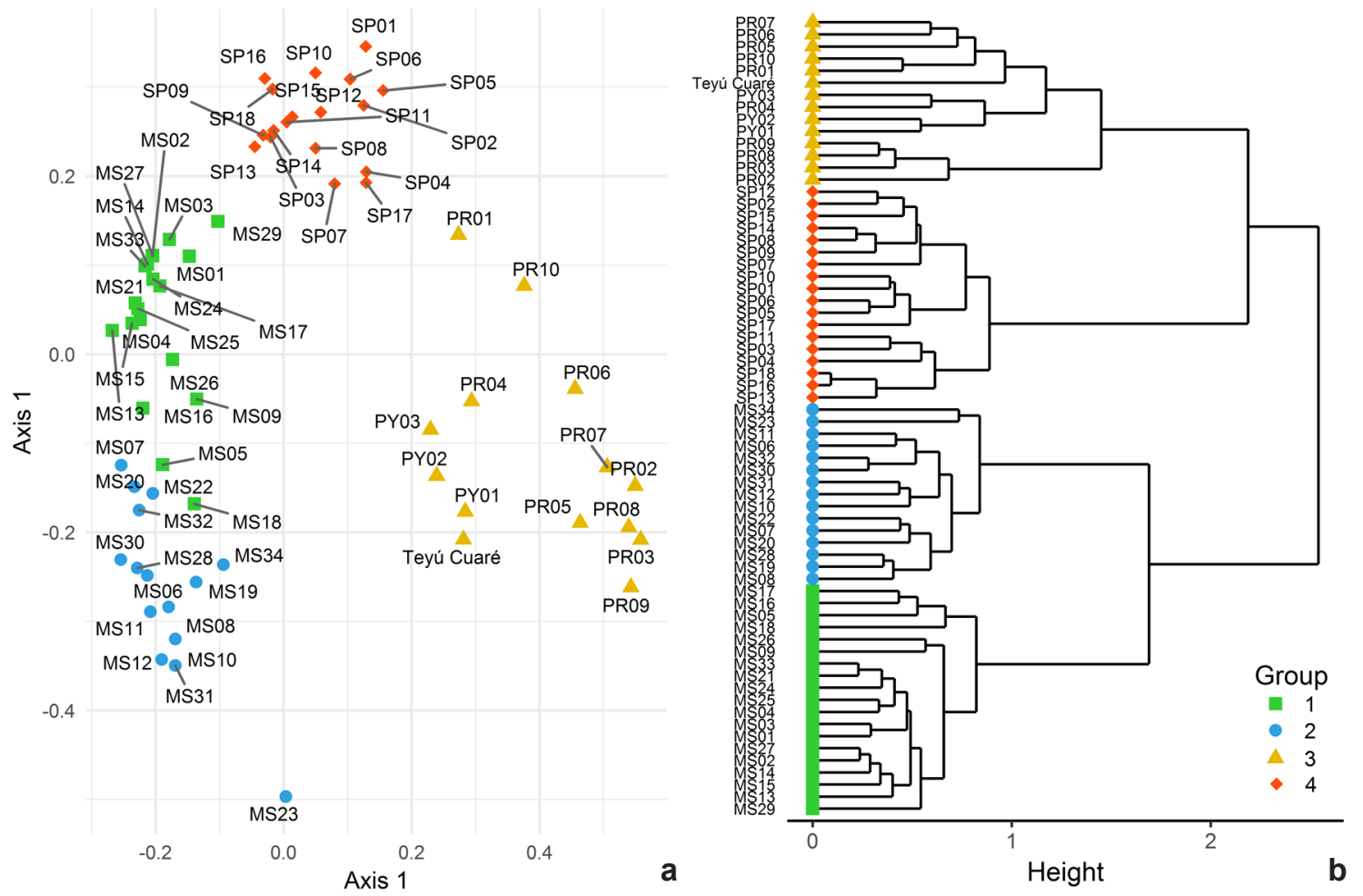

Figure 6 - Ordination diagram yielded by PCoA (a) and dendrogram (b) for trees and large shrubs of 66 Cerrado's area from Brazil, Paraguay, and Argentina -Teyú Cuaré-. Each color and shape represent different group derived from a the Ward's hierarachical methods.

the last five years, at least eight burnings were registered in the savanna, while the last forest fire occurred in 2002.

Permanence of distinct vegetation patches/ islands (relicts) can be maintained by local factors such as lithology, hydrology, topography and paleobotany (Ab'Sáber 1962), but its origins can be explained by changing distribution of vegetation domains during the Quaternary (Ab'Sáber 2003). During this period, the biomes distribution was influenced by glacial and interglacial cycles (Cox $\&$ Moore 2011). According to Refuge Theory, distribution patterns of flora and fauna of tropical America are the consequence of spatial dynamics (i.e. expansion and retraction) due to climatic fluctuation (Haffer 1969; Ab'Sáber 1992; Haffer $\&$ Prance 2002). Considering this, it is possible to indicate that the current distribution of savannas and seasonally dry forest in the Neotropics is related to the climatic variations of the Quaternary (Pennington et al.2000). Changes in the distribution of Neotropical savannas are well documented in the literature and proved by different approaches, such as the use of carbon isotope (Sanaiotti et al. 2002), pollen studies (Behling 1995), paleodistribution modelling (Bueno et al. 2016) or combination of phylogeographical and species distribution modelling (Collevatti et al. 2012).

In the actual interglacial period, which started 10,000 years BP (Holocene), due to a warmer and wetter climate and ice retraction, many taxa have drastically changed their geographic distribution (Lomolino et al. 2010). Concerning the Quaternary, the Pleistocene climate was cold and dry, while the early and middle Holocene was warm and dry, becoming wetter and stable later (Gessert et al. 2011). It is possible that during the middle Holocene, grasslands, and savannas had covered the entire Southern Misiones. Carbon dating in Oberá town (Misiones - Argentina) determined that from 7,500 to 3,000 years BP there was an expansion of $\mathrm{C} 4$ plants along the $\mathrm{S}-\mathrm{N}$ transect, indicating an increase of aridity in that period that changed after 3,000 years BP, when the climate became wetter (Zech et al. 2009). Other studies proved that in Southern Brazil and some 
Misiones regions, the climate became wetter and less seasonal in the last 2,000 years, allowing the replacement of open vegetation types and dry forest (Misiones) with Araucaria forest (Behling 2002; Behling \& Pillar 2007; Iriarte \& Behling 2007; Gessert et al. 2011). This forest expansion was overlapped by the advance of farmers and potters of the Taquara/Itararé Tradition (Iriarte \& Behling 2007), that reached Paraná state around 4,000 years ago (Parellada 2009).

Advance and retreat dynamics of these biomes and their relationship with different human cultures could have happened in Misiones, according to the rich archaeological evidence. It indicates that different old civilizations inhabited the region for thousands of years. Among the most ancient (8,000 years ago), there are archaeological remains of the Umbu Tradition, strongly associated with grasslands, and from hunter-gatherer groups, possibly related to the Humaitá Tradition (Dias \& Hoeltz 2010). The Guarani group arrived in the region c. 1000 years ago (IPEC 2012), while the Jesuits settled close to Paraná river right after the Guayrá Exodus in 1631, founding San Ignacio Miní and Nuestra Señora de Loreto (Belastegui 2006). Despite the Guarani inhabiting sylvan environments, they have adapted to forest edges and grasslands, developing some hunting techniques associated with these kind of environments, as indicated by the use of boleadeiras, a tool that was found together with Guarani ceramics in San Ignacio (see supplementary material 4: <http:// dx.doi.org/10.6084/m9.figshare.5238961>).

Transitional vegetation types between savanna vegetation and forest are controlled by chemical and physical soil properties such as cation capacity exchange (Veenendaal et al 2015), potassium (Lloyd et al. 2015), aluminum saturation or clay (Ruggiero et al. 2002). In the Teyú Cuaré field, the soil profile of savannas shows higher concentration of aluminum saturation, and lower concentration of organic carbon, base saturation and phosphorous than the soil profile of forests, which could suggest that chemical soil conditions are different between those physiognomies. Despite that in both vegetation types the soil presents sandy texture. It has been proved that sandy and welldrained soil could act as an environmental filter, promoting more stressful condition for propagules of mesic species in open formations (SaporettiJunior et al. 2012).

There are three dynamics between forestsavanna boundary zones: (i) the forest can advance over the savanna; (ii) the savanna advances into the forest, (iii) or both are in equilibrium (Hopkins 1992). We inferred that the first of them is occurring in the studied site. We observed that the forest-savanna transition is almost abrupt, a normal characteristic of this physiognomy boundary (Hopkins 1992; Cole 1992). However, some patches were dominated by pioneer and early secondary species. An explanation for this arboreal pioneer colonization can be attributed to periodic burning (Fontana 2005) in those areas. We highlighted that the majority of plots showed traces of previous burns, evidenced by carbonized corks. Fire is a disturbance agent present at global level (Miranda et al. 2002; Walter et al. 2008; Hutley \& Setterfield 2008) and is the second most important factor that controls this forestsavanna dynamic (Hopkins 1992). Many studies, in different Cerrado physiognomies, have shown the effect of burning on soil nutrient and woodyherb components; and how it helps to maintain open communities (Kaufmann et al. 1994; Pivello \& Coutinho 1996; Felfili et al. 2000; Hoffmann et al. 2003; Miranda \& Sato 2005; Moreira 2008; Pivello et al. 2010; Oliveras et al. 2013), acting as an important environmental filter (Carvalho \& Batalha 2013). Thus, some researchers support the use of fire to maintain the diversity of this kind of vegetation (Ramos-Neto \& Pivello 2000; Fontana 2005; Pivello 2005; Moreira 2008; Oliveras et al. 2013). In fact, another savanna patch allocated c. $1 \mathrm{~km}$ from the studied area (55'33'10.04'"W and $\left.27^{\circ} 15^{\prime} 54.19^{\prime} \mathrm{S}\right)$, the absence of fire promoted a denser woody vegetation.

The forest colonization rate depends on the severity and frequency of fire (Hopkins 1992; Pinheiro \& Durigan 2009; Oliveras et al. 2013). The gradual conversion of open vegetation to shrub and forest areas would happen though the complete inhibition of burnings (Pinheiro \& Durigan 2009), as fire precludes the establishment of arboreal seedlings and benefits herbaceous species or fire-adapted trees (Ferri 1973; Walter et al. 2008; Hutley \& Setterfield 2008). This situation not only benefits grasslands but also the growth of grasses and promotes the subsequent combustible material accumulation (Hutley \& Setterfield 2008). The opposite process occurs when arboreal species established in savanna, and in absence of fire, they gradually develop a dense canopy, which hampers light entry to the detriment of the herbaceous layer, helping the maintenance of the arboreal community (Hopkins 1992; Hutley \& Setterfield 2008). The 
previously explained process happens in the study area because there is evidence of recurrent burns (eight in the last five years), the most important species is a well adapted to fire, and many of the herbaceous species have fire resistant traits, such as subterranean or cork stems, xylopodium and clumped species. Also, there are species common in other savannas that apparently reach here their southern distribution limits: Allagoptera campestris, Calliandra longipes, Ditassa acerosa, Eryngium juncifolium, Leptolobium elegans, Macrosiphonia virescens, Qualea cordata, and Sporobolus acuminatus var. longispiculus.

Despite the need for more studies to elucidate accurately the biogeographical and historical processes that determined the peculiar flora of Teyú Cuaré field, it would be feasible to conclude that this grassland-savanna vegetation type is a vestige of the late Pleistocene and middle Holocene climate conditions. The maintenance of this vegetation type is related to geological and edaphic conditions, such as sandy, acid, dystrophic and strongly drained soils, combined with recurrent fires, possibly linked to ancient cultures and current burnings.

\section{Conclusion}

Leptolobium elegans stood out as the main woody species in the area, presenting the most important structural values. The structure of the savannah site was similar to other sites of typical Cerrado in Paraná and São Paulo states in Brazil.

The woody vegetation of this savanna is floristically closely related to that in the southern areas of Cerrado sites, mainly with Amambay and Canindeyú department in Paraguay, and Paraná state in Brazil. The vegetation of Teyú Cuaré field is probably an expression of the open formation that prevailed in Misiones province and Southern Brazil in the late Pleistocene and middle Holocene; this condition was probably reversed after 3,000 years BP when the climate became more favorable to forest development (Zech et al. 2009).

Considering the actual climate condition and the records of pioneer and late secondary species, the area exhibits a gradual advance of the forest through the grassland. However, the open physiognomies still remain through mechanisms that work at different levels, such as geological, edaphic and anthropological aspects, this last associated with fire. In this sense, the total inhibition of burns could reduce the herbaceous layer promoting a structural and floristic shift. For this reason, the use of fire could be a feasible tool to maintain the characteristics of this particular and biogeographically valuable site.

In order to achieve more in-depth conclusions, we recommend additional studies comparing Teyú Cuaré floristics and vegetation structure with Cerrado areas from Paraguay and Brazil, but considering all life forms, specially taxa from the herb stratum.

\section{Acknowledgments}

We thank Marília Borgo, Lucas López and Victoria Clifford for reviewing the manuscript, the anonymous reviewers for their valuable comments and suggestions, and María Paula Bertolini for logistic support. Thanks to Fundación Temaikén and Ministerio de Ecología y Recursos Naturales Renovables y Turismo de la Provincia de Misiones. Also, we acknowledge the financial support from the Facultad de Ciencias Forestales, Universidad Nacional de Misiones and Coordenação de Aperfeiçoamento de Pessoal de Nível Superior.

\section{References}

Ab'Sáber AN (1962) Contribuição à geomorfologia da área dos cerrados. In: Simpósio sobre o Cerrado 1. Edusp, São Paulo. Pp. 117-124.

Ab'Sáber AN (1992) A teoria dos refúgios: origem e significado. In: Anais $2^{\circ}$ Congresso Nacional sobre Essências Nativas. Ed. especial. Vol. 4. Instituto Florestal, São Paulo. Pp. 29-34.

Ab'Sáber AN (2003) Os domínios de natureza no Brasil: potencialidades paisagísticas. Atelie Editorial, São Paulo. 159p.

Alizadeh K, Cohen M \& Behling H (2015) Origin and dynamics of the northern South American coastal savanna belt during the Holocene - the role of climate, sea-level, fire and humans. Quaternary Science Reviews 122: 51-62.

Behling H \& Pillar VD (2007) Late Quaternary vegetation, biodiversity and fire dynamics on the southern Brazilian highland and their implication for conservation and management of modern Araucaria forest and grassland ecosystems. Philosophical Transactions Royal Society B 362: 243-251.

Behling H (1995) A high resolution Holocene pollen record from Lago do Pires, SE Brazil: vegetation, climate and fire history. Journal of Paleolimnology 14: 253-268.

Behling H (2002) South and southeast Brazilian grasslands during Late Quaternary times: a synthesis. Palaeogeography, Palaeoclimatology, Palaeoecology 117: 19-27.

Belastegui HM (2006) Los colonos de Misiones. Editorial Universitaria de Misiones, Posadas. 180p. 
Biganzoli F \& Romero MEM (2004) Inventario florístico del Parque Provincial Teyú Cuaré y Alrededores (Misiones, Argentina). Darwiniana 42: 1-24.

Bilenca D \& Miñarro F (2004) Identificación de Áreas Valiosas de Pastizal (AVPs) en las Pampas y Campos de Argentina, Uruguay y sur de Brasil. Fundación Vida Silvestre Argentina, Buenos Aires. 323p.

Boyle B, Hopkins N, Lu Z, Garay JAR, Mozzhrin D, Rees T, Matasci N, Narro ML, Piel WH, Mckay SJ, Lowry S, Freeland C, Peet RK \& Enquist BJ (2013) The taxonomic name resolution service: an online tool for automated standardization of plant names. BMC bioinformatics 14: 16 .

Bueno ML, Pennington RT, Dexter KG, Kamino LHY, Pontara V, Neves DM, Ratter JA \& OliveiraFilho AT (2016) Effects of Quaternary climatic fluctuations on the distribution of Neotropical savanna tree species. Ecography 39: 001-012.

Burkart AE (1952) Las leguminosas argentinas, silvestres y cultivadas. $2^{\text {a }}$ ed. Acme Agency, Buenos Aires. 590p.

Cabrera AL (1987) Una nueva especie de Vernonia (Compositae) de Misiones, República Argentina. Darwiniana 28: 187-189.

Carmo MRB, Andrade ALP, Santos GASD \& Assis MA (2012) Análise estrutural em relictos de cerrado no parque estadual do Guartelá, município de Tibagi, estado do Paraná, Brasil. Ciência Florestal 22: 505-517.

Carneiro Filho A (1993) Cerrados amazônicos: fósseis vivos? Algumas reflexões. Revista IG 14: 63-68.

Carvalho GH \& Batalha MA (2013) The drivers of woody species richness and density in a Neotropical savannah. Biology letters 9. DOI: 10.1098/ rsbl.2013.0412.

Chébez JC (1996) Misiones Ñú. Campos Misioneros, algo más que el confín de la selva. Nuestras aves. Asociación Ornitológica del Plata 34: 4-16.

Cole B (1992) Ecological processes at the forest savanna boundary. In: Furley PA, Proctor J \& Ratter JA (eds.) Nature and dynamics of forest-savanna boundaries. Chapman and Hall, London. Pp. 21-33.

Collevatti RG, Terribile LC, Lima-Ribeiro MS, Nabout JC, Oliveira G, Rangel TF, Rabelo SG \& DinizFilho JAF (2012) A coupled phylogeographical and species distribution modelling approach recovers the demographical history of a Neotropical seasonally dry forest tree species. Molecular Ecology 21: 5845-5863.

Colwell RK (2013) EstimateS: Statistical estimation of species richness and shared species from samples. Version 9. Available at $<$ http://viceroy.eeb.uconn. edu/estimates/>. Access on 26 January 2016.

Colwell RK, Chao A, Gotelli NJ, Lin SY, Mao CX, Chazdon RL \& Longino JT (2012) Models and estimators linking individual-based and sample- based rarefaction, extrapolation, and comparison of assemblages. Journal of Plant Ecology 5: 3-21.

Cox CB \& Moore PD (2011) Biogeografia: uma abordagem metodológica e evolucionária. $7^{\mathrm{a}}$ ed. Grupo Editorial Nacional, Rio de Janeiro. 398 p.

Dias AS \& Hoeltz SE (2010) Indústrias líticas em contexto: o problema Humaitá na arqueologia sul brasileira. Revista de Arqueologia 23: 40-67.

Durigan G (2006) Observations on the Southern Cerrados and their Relationship with the Core Area. In: Pennington RT, Lewis GP \& Ratter JA (eds.) Neotropical Savannas and seasonally dry forests plant diversity, biogeography, and conservation. CRC Press, Boca Raton. 504p.

Durigan G, Nishikawa DLL, Rocha E, Silveira ER, Pulitano FM, Regalado LB, Carvalhaes MA, Paranaguá PA \& Ranieri VEL (2002) Caracterização de dois estratos da vegetação em uma área de cerrado no município de brotas, SP, Brasil. Acta Botanica Brasilica 16: 251-262.

Epling CC (1949). Revisión del género Hyptis (Labiatae). Revista del Museo de la Plata, Sección Botánica 7: 153-497.

Farinaccio MA \& Keller HA (2014) Novelties in Oxypetalum (Apocynaceae-Asclepiadoideae) for the Argentine Flora. Phytotaxa 184: 109-114.

Felfili JM, Rezende AV, Silva Júnior C \& Silva MA (2000) Changes in the floristic composition of cerrado sensu stricto in Brazil over a nine-year period. Journal of Tropical Ecology 16: 579-590.

Ferri MG (1973) Sobre a origem, a manutenção e a transformação dos cerrados. Ecologia 1: 5-10.

Filgueiras TS (1990) Revisão de Mesosetum Steudel (Gramineae: Paniceae). Acta Amazonica 19: 47-114.

Fontana JL (2005) Una propuesta para la conservación de los pajonales del Diplothemio-Axonopodetum. San Ignacio, Provincia de Misiones (Argentina). Facena 21: 55-67.

Garrasino CAF (1995) Provincia de Misiones. Algunas alternativas exploratorias. Parte II. Boletín de Informaciones Petroleras. REPSOL YPF, Buenos Aires. Pp. 60-98.

Gessert S, Iriarte J, Ríos RC \& Behling H (2011) Late Holocene vegetation and environmental dynamics of the Araucaria forest region in Misiones Province, NE Argentina. Review of Palaeobotany and Palynology 166: 29-37.

Haffer J (1969) Speciation in Amazonian forest birds. Science 165: 131-137.

Haffer J \& Prance GT (2002) Impulsos climáticos da evolução na Amazônia durante o Cenozóico: sobre a teoria dos Refúgios da diferenciação biótica. Estudos avançados 16: 175-206.

Harrington JH (1950) Geología del Paraguay Oriental. Contribuciones Científicas Serie E, Geología 1: $1-88$. 
Hoffmann WA, Birgit O \& Nascimento PKV (2003) Comparative fire ecology of tropical savanna and forest trees. Functional Ecology 17: 720-726.

Hopkins B (1992) Ecological processes at the forest savanna boundary. In: Furley PA, Proctor J \& Ratter JA (eds.) Nature and dynamics of forest-savanna boundaries. Chapman and Hall, London. Pp. 21-33.

Hutley LB \& Setterfield SA (2008) Savanna In: Jørgensen SE (eds.) Encyclopedia of ecology. Vol. 4. Elsevier, Amsterdam. Pp. 3143-3154.

INTA - Instituto Nacional de Tecnología Agropecuaria (1990) Atlas de suelos de la República Argentina. Instituto Nacional de Tecnología Agropecuaria, Buenos Aires. 1600p.

IPEC - Instituto Provincial de Estadística y Censos. (2012) Gran atlas de Misiones. Instituto Provincial de Estadística y Censos, Posadas. Pp. 66-98. Available at $<$ https://www.scribd.com/document/339845268/ Gran-Atlas-de-Misiones-Cap-3-Historia-pdf $>$. Access on 17 January 2016.

Iriarte J \& Behling H (2007) The expansion of Araucaria forest in the southern Brazilian highlands during the last 4000 years and its implications for the development of the Taquara/Itararé Tradition. Environmental Archaoeogy 12: 115.127.

Ishara KL \& Maimoni-Rodella RCS (2010) Community structure and comparative analysis of the woody component of a cerrado remnant in Southeastern Brazil. Hoehnea 37: 199-210.

Ishara KL (2010) Aspectos florísticos e estruturais de três fisionomias de cerrado no município de Pratânia. Tese de Doutorado. Universidade Estadual Paulista "Júlio de Mesquita Filho", Botucatú, São Paulo. 156p.

IUSS - International Union of Soil Sciences, Working Group WRB (2015) World reference base for soil resources 2014 update 2015. International soil classification system for naming soils and creating legends for soil maps. World Soil Resources Reports $\mathrm{n}^{\circ}$. 106. FAO, Rome. 192p.

Kaufmann JB, Cummings DL \& Ward DE (1994) Relationships of fire, biomass and nutrient dynamics along a vegetation gradient in the Brazilian cerrado. Journal of Ecology 82: 519-531.

Keller HA \& Tressens SG (2016) Hedeoma teyucuarensis (Lamiaceae), nueva especie de Misiones, Argentina. Darwiniana, nueva serie 4: 5-11.

Keller HA (2015) Austrochthamalia teyucuarensis (Apocynaceae: Asclepiadoideae), una nueva especie endémica d Misiones, Argentina. Lilloa 52: 40-45.

Krapovickas A (2012a) Novedades en el género Gaya (Malvaceae). Bonplandia 21: 71-76.

Krapovickas A (2012b) Novedades en las secciones Cordifoliae, Distichifolia, Malacroidea, Muticae y Nelavaga del género Sida (Malvaceae). Bonplandia 21: 77-92.
Ledru MP (2002) Late Quaternary history and evolution of the Cerrados as revealed by palynological records. In: Oliveira PS \& Marquis RJ (ed.) The Cerrados of Brazil: ecology and natural history of a Neotropical Savanna. Columbia University Press, New York. Pp. 33-50.

Lloyd J, Domingues TF, Schrodt F, Ishida FY, Feldpausch TR, Saiz G, Quesada CA, Schwarz M, TorelloRaventos M, Gilpin M, Marimon MS, MarimonJunior BH, Ratter JA, Grace J, Nardoto GB, Veenendaal E, Arroyo L, Villarroel D, Killeen TK, Steiningera M \& Phillips OL (2015) Edaphic, structural and physiological contrasts across Amazon Basin forest-savanna ecotones suggest a role for potassium as a key modulator of tropical woody vegetation structure and function. Biogeosciences 12: 6529-6571. DOI: <https://doi. org/10.5194/bg-12-6529-2015>.

Lomolino ML, Riddle BR, Whittaker RJ \& Brown JH (2010) Biogeography. $4^{\text {th }}$ ed. Sinauer, Sunderland. $764 \mathrm{p}$.

Lorenzi H (2000) Árvores brasileiras. Manual de identificação e cultivo de plantas arbóreas nativas do Brasil. Vol. 1. $3^{\text {a }}$ ed. Instituto Plantarum, Nova Odessa. 368p.

Martínez-Crovetto R (1963) Esquema fitogoegráfico de la Provincia de Misiones (República Argentina). Bonplandia 1: 171-224.

Mayle FE (2006) The late Quaternary biogeographical history of South American Seasonally Dry Tropical Forests: insights from palaeo-ecological data. In: Pennington RT, Lewis GP \& Ratter JA (eds.) Neotropical savannas and seasonally dry forests plant diversity, biogeography, and conservation. CRC Press, Boca Raton. Pp. 396-416.

Meira Neto JAA (1991) Composição florística e fitossociologia de fisionomias de vegetação de cerrado sensu lato da estação ecológica de Santa Barbara (E.E.S.B.), município de Águas de Santa Barbara, estado de São Paulo. Tese de Mestrado. Universidade Estadual de Campinas, Campinas. $117 \mathrm{p}$.

Mendonça RC, Felfili JM, Walter BMT, Silva Júnior MC, Rezende AV, Filgueiras TS, Nogueira PE \& Fagg CW (2008) Flora vascular do bioma Cerrado: checklist com 12.356 espécies. In: Sano SM, Almeida SP \& Ribeiro JF (eds). Cerrado: ecologia e flora. Vol. 2. Embrapa Cerrados/Embrapa Informação Tecnológica, Brasília. Pp. 421-442.

Mereles MF (2013) Acerca de las extensiones de Cerrados y Cerradones en el Paraguay. Paraquaria Natural 1: 63-68.

Miranda HS \& Sato MN (2005) Efeitos do fogo na vegetação lenhosa do Cerrado. In: Scariot A, SouzaSilva JC \& Felfili JM (org.) Cerrado: ecologia, biodiversidade e conservação. Ministério do Meio Ambiente, Brasília. Pp. 93-105. 
Miranda HS, Bustamante MMC \& Miranda AC (2002) The fire factor. In: Oliveira PS \& Marquis RJ (eds.) The Cerrados of Brazil: ecology and natural history of a Neotropical Savanna. Columbia University Press, New York. Pp. 51-68.

Moreira AG (2008) Effects of fire protection on savanna structure in Central Brazil. Journal of Biogeography 27: 1021-1029.

Moro MF, Castro ASF \& Araújo FS (2011) Composição florística e estrutura de um fragmento de vegetação savânica sobre os tabuleiros pré-litorâneos na zona urbana de Fortaleza, Ceará. Rodriguésia 62: 407-423.

Moro MF, Macedo MB, Moura-Fé MM, Castro ASF \& Costa RC (2015) Vegetação, unidades fitoecológicas e diversidade paisagística do estado do Ceará. Rodriguésia 66: 717-743.

Moro RS (2012) Padrões biogeográficos dos relictos de cerrado no Campos Gerais. In: Moro RS (org.) Biogeografia do bioma Cerrado. Ed. UEPG, Ponta Grossa. Pp. 53-67.

Mueller-Dombois D \& Ellenberg H (1974) Aims and methods of vegetation ecology. John Wiley \& Sons, New York. 547p.

Oliveira ACP, Penha AS, Souza RF, \& Loiola MIB (2012) Composição florística de uma comunidade savânica no Rio Grande do Norte, Nordeste do Brasil. Acta Botanica Brasilica 26: 559-569.

Oliveras I, Meirelles ST, Hirakuri VL, Freitas CR, Miranda HS \& Pivello VR (2013) Effects of fire regimes on herbaceous biomass and nutrient dynamics in the Brazilian savanna. International Journal of Wildland Fire 22: 368-380.

Parellada CI (2009) Arte rupestre no Paraná. Revista Científica da Faculdade de Artes do Paraná 4: 1-25.

Pennington G (2006) An overview of the plant diversity, biogeography and conservation of Neotropical Savannas and Seasonally Dry Forests. In: Pennington RT, Lewis GP \& Ratter JA (eds.) Neotropical Savannas and Seasonally Dry Forests Plant Diversity, Biogeography, and Conservation. CRC Press, Boca Raton. Pp. 1-32.

Pennington RT, Prado DE \& Pendry CA (2000) Neotropical seasonally dry forests and Quaternary vegetation changes. Journal of Biogeography 27: 261-273.

Pérez-García EA \& Meave JA (2004) Heterogeneity of xerophytic vegetation of limestone outcrops in a tropical deciduous forest region in southern México. Plant Ecology 175: 147-163.

Pinheiro ES \& Durigan G (2009) Dinâmica espaçotemporal (1962-2006) das fitofisionomias em unidade de conservação do Cerrado no sudeste do Brasil. Revista Brasileira de Botânica 32: 441-454.

Pivello VR \& Coutinho LM (1996) A qualitative successional model to assist in the management of
Brazilian cerrados. Forest Ecology and Management 87: 127-138.

Pivello VR (2005) Manejo de fragmentos de Cerrado: princípios para a conservação da biodiversidade. In: Scariot A, Souza-Silva JC \& Felfili JM (orgs.) Cerrado: ecologia, biodiversidade e conservação. Ministério do Meio Ambiente, Brasília. Pp. 401-414.

Pivello VR, Oliveras I, Miranda HS, Haridasan M, Sato MN \& Meirelles ST (2010) Effect of fires on soil nutrient availability in an open savanna in Central Brazil. Plant and Soil 337: 111-123.

Prado Júnior JA, Lopes SF, Vale VS, Dias Neto OC \& Schiavini I (2012) Comparação florística, estrutural e ecológica da vegetação arbórea das fitofisionomias de um remanescente urbano de cerrado. Bioscience Journal 28: 456-471.

R Core Team (2016) R: a language and environment for statistical computing. R Foundation for Statistical Computing, Vienna. Available at $<$ https://www.Rproject.org/>. Access on 3 June 2016.

Ramos-Neto MB \& Pivello VR (2000) Lightning fires in a Brazilian savanna national park: rethinking management strategies. Environmental Management 26: 675-684.

Ratter JA, Bridgewater S \& Ribeiro JF (2003) Analysis of the floristic composition of the Brazilian cerrado vegetation III: comparison of the woody vegetation of 376 areas. Edinburgh Journal of Botany 60: 57-109.

Ribeiro JF \& Walter BMT (2014) As principais fitofisionomias do bioma Cerrado. In: Sano SM, Almeida SP \& Ribeiro JE (eds.) Cerrado, ecologia e flora. Vol. 1. EMBRAPA, Brasilia. Pp. 151-212.

Ritter L (2008) Composição florística e aspectos físicos do cerrado nos campos gerais, Paraná. Dissertação de Mestrado. Universidade Estadual de Ponta Grossa, Ponta Grossa. 130p.

Rodrigues RS \& Tozzi AMGA (2012) Revisão taxonômica de Leptolobium (Papilionoideae, Leguminosae). Acta Botanica Brasilica 26: 146-164.

Ruggiero PGC, Batalha MA, Pivello VR \& Meirelles ST (2002) Soil-vegetation relationships in cerrado (Brazilian savanna) and semideciduous forest, Southeastern Brazil. Plant Ecology 160: 1-16.

Rull V, Montoya E, Nogué S, Vegas-Vilarrúbia T \& Safont E (2013) Ecological palaeoecology in the neotropical Gran Sabana region: long-term records of vegetation dynamics as a basis for ecological hypothesis testing. Perspectives in Plant Ecology, Evolution and Systematics 15: 338-359.

Sanaiotti TM, Martinelli LA, Victoria RL, Trumbore SE \& Camargo PB (2002) Past vegetation changes in Amazon Savannas determined using carbon isotopes of soil organic matter 1. Biotropica 34: 2-16.

Saporetti-Junior AW, Schaefer CEGR, Souza AL, Soares MP, Araújo DSD \& Meira-Neto JAA (2012) 
Influence of soil physical properties on plants of the mussununga ecosystem, Brazil. Folia Geobotanica 47: 29-39.

Sarmiento G (1984) The ecology of Neotropical Savannas. Harvard University Press, Cambridge. $256 \mathrm{p}$.

Spezialea KL \& Ezcurra C (2012) The role of outcrops in the diversity of Patagonian vegetation: relicts of glacial palaeofloras? Flora 207: 141-149.

Tchilinguirián P, Cavallaro S, Ducos E, Fratalocchi C, Marengo H, Palma YL, Tejedo A, Tobio ML, Toloczyki M \& Portaneri J (2005) Estudio geocientífico aplicado al ordenamiento territorial, San Ignacio. Servicio Geológico Argentino, Instituto Federal de Geociencias y Recursos Naturales Alemania, Buenos Aires. 97p.

Teruggi ME (1970) Bosquejo geológico del Paraguay y la provincia de Corrientes. Boletín de la Sociedad Argentina de Botánica 11: 1-15.

Toppa RH (2004) Estrutura e diversidade florística das diferentes fisionomias de Cerrado e suas correlações com o solo na Estação Ecológica de Jataí, Luís Antônio, SP. Tese de Doutorado. Universidade Federal de São Carlos, São Carlos. 149p.

Uhlmann A, Galvão F \& Silva AM (1998) Análise da estrutura de duas unidades fitofisionômicas de savana (cerrado) no sul do Brasil. Acta Botanica Brasilica 12: 231-247.

Veenendaal EM, Torello-Raventos M, Feldpausch TR, Domingues TF, Gerard F, Schrodt F, Saiz G, Quesada CA, Djagbletey G, Ford A, Kemp J, Marimon BS, Marimon-Junior BH, Lenza E, Ratter JA, Maracahipes L, Sasaki D, Sonké B, Zapfack L, Villarroel D, Schwarz M, Yoko Ishida F, Gilpin M, Nardoto GB, Affum-Baffoe K, Arroyo L, Bloomfield K, Ceca G, Compaore H, Davies K, Diallo A, Fyllas NM, Gignoux J, Hien F, Johnson M, Mougin E, Hiernaux P, Killeen T, Metcalfe D,
Miranda HS, Steininger M, Sykora K, Bird MI, Grace J, Lewis S, Phillips OL \& Lloyd J (2015) Structural, physiognomic and above-ground biomass variation in savanna-forest transition zones on three continents - how different are co-occurring savanna and forest formations? Biogeosciences 12: 2927-2951.

Velazco SJE (2014) Estudo florístico e fitossociológico de três comunidades vegetais em San Ignacio, província de Misiones, Argentina. Tese de Mestrado. Universidade Federal do Paraná, Curitiba. 180p.

Velazco SJE, Galvão F, Keller HA \& Bedrij NA (2015) Florística e fitossociologia de uma floresta estacional semidecidual, reserva privada Osununú-Misiones, Argentina. Floresta e Ambiente 22: 1-12.

Villarroel D, Pinto JN, Centurión TR \& Parada A (2009) Relación de la cobertura leñosa con la riqueza herbácea en tres fisionomías del Cerrado sensu lato (Cerro Mutún, Santa Cruz, Bolivia). Ecología en Bolivia 44: 89-98.

Walter BM, Carvalho AM \& Ribeiro JF (2008) O conceito de Savana e de seu componente Cerrado. In: Sano SM, Almeida SP \& Ribeiro JF (eds.) Cerrado: ecologia e flora. EMBRAPA-CPAC, Planaltina. Pp. 19-25.

Werneck FP (2011) The diversification of eastern South American open vegetation biomes: historical biogeography and perspectives. Quaternary Science Reviews 30: 1630-1648.

Zech W, Zech M, Zech R, Peinemann N, Morras HJM, Moretti L, Ogle N, Kalim RM, Fuchs M, Schad P \& Glaser B (2009) Late Quaternary palaeosol records from subtropical $\left(38^{\circ} \mathrm{S}\right)$ to tropical $\left(16^{\circ} \mathrm{S}\right)$ South America and palaeoclimatic implications. Quaternary International 196: 107-120.

Zuloaga FO, Morrone O \& Rodriguez D (1999) Análisis de la biodiversidad en plantas vasculares de la Argentina. Kurtziana 27: 17-167. 